\title{
POLITICAL MARKETING POLITISI PEREMPUAN DI MEDIA SOSIAL (ANALISIS RETORIKA PUBLIK PADA AKUN INSTAGRAM @puti_soekarno)
}

\section{Ruvira Arindita, S.Ikom, M.Si (ruvira.arindita@gmail.com)}

Harza Putra Hartanto (harzaputrahartanto@gmail.com)

\begin{abstract}
Abstrak
Partisipasi perempuan Indonesia dalam kancah politik semakin meningkat. Salah satu sosok politisi perempuan yang mencuri perhatian adalah Puti Guntur Soekarno Sebelumnya sudah cukup banyak keturunan presiden RI pertama yang aktif dalam politik praktis bahkan Megawati Soekarno Putri berhasil terpilih menjadi presiden perempuan pertama di negeri ini. Kemunculan Puti sebagai Calon Wakil Gubernur Jawa Timur mengukuhkan regenerasi politisi perempuan dalam trah Soekarno. Namun tidak cukup dengan mengandalkan nama besar keluarga, untuk memperkenalkan diri ke hadapan konstituen Puti harus memiliki strategi tertentu. Peneliti tertarik untuk mengetahui bagaimana Political Marketing yang dilakukan oleh Puti melalui Retorika Publik di akun Media Sosial. Metode yang digunakan dalam penelitian ini adalah analisis isi dengan pendekatan kualitatif. Unit analisis adalah foto-foto dari akun Instagram @ puti_soekarno yang diunggah selama periode Pilkada yaitu Februari - Juni 2018. Kemudian foto, keterangan foto dan tanda pagar (hashtags) yang dipakai akan dianalisis berdasarkan teori Retorika Publik Aristoteles (Ethos, Pathos, Logos) dan dikaitkan dengan kategori Political Marketing Peter Montoya (Kebijakan, Figur, Partai dan Pencitraan). Berdasarkan temuan peneliti, kategori Political Marketing yang paling dominan digunakan oleh Puti adalah Figur dan Partai. Upaya political marketing tersebut didukung oleh gaya Retorika Publik yang mengedepankan Pathos (membangkitkan emosi positif) dan Ethos (menunjukkan kredibilitas komunikator) dibandingkan Logos (logika).
\end{abstract}

Kata Kunci: Politisi Perempuan, Political Marketing, Retorika Publik Aristoteles, Media Sosial

Political Marketing of Female Politician in Social Media (Public Rhetoric Analysis at Instagram Account @puti_soekarno) 
Participation of Indonesian women in political practice has increased in number. Puti Guntur Soekarno is one of those who has attracted public interest. Previously, there have been quite a lot of Indonesian's first president's descendants who involved in political world even Megawati Soekarno Putri was elected as first Indonesian president in this country. Puti's debut as candidate of East Java's Governor in this year's Regional Election has strenghtened the regeneration of female politician in Soekarno family. However it would not be sufficient to just rely on the big names of Soekarno, Puti has to have a strategy to attract the constituent. Researcher is interested to explore how the political marketing that Puti uses through the public rhetoric style at her social media account. The method used is content analysis with qualitative approach. The unit analysis used is the pictures at her official Instagram account (@ puti_soekarno) that have been uploaded during Regional Election period (February - June 2018). Furthermore, the pictures, captions and hashtags used will be analysed based on Aristotles' Public Rhetoric theory and be connected to the concepts of Political Marketing of Peter Montoya. The interesting findings from this research is that Puti still uses the strength of her political party as well as the famous figures related to her as her main political marketing strategy. Her political marketing is supported by her public rhetorical style that prioritised ethos and pathos over logos.

Keywords: female politician,political marketing, Aristotles' public rhetoric, social media

\section{Pendahuluan}

Demokrasi mengamanatkan adanya persamaan akses dan peran serta penuh bagi laki-laki maupun perempuan, atas dasar prinsip persamaan derajat dalam semua wilayah dan tataran kehidupan publik, terutama dalam posisi-posisi pengambilan keputusan. Platform Aksi Beijing dan Konvensi tentang Penghapusan Segala Bentuk Diskriminasi terhadap Perempuan (Convention on the Elimination of All Forms of Discrimination Against Women atau CEDAW) merekomendasikan agar semua pemerintah di dunia agar memberlakukan kuota sebagai langkah khusus yang bersifat sementara untuk meningkatkan jumlah perempuan di dalam jabatan-jabatan appointif (berdasarkan penunjukan/pengangkatan) maupun elektif (berdasarkan hasil pemilihan) pada tingkat pemerintahan lokal dan nasional. 
Di Indonesia, Partisipasi Wanita dalam Kancah dunia Politik di Indonesia sudah bukanlah hal asing walau tingkat Partisipasinya masih kurang. Pilkada adalah salah satu ajang bagi para Politikus Wanita untuk unjuk gigi. Dikutip dari BBC Indonesia, Pilkada serentak 2018 setidaknya akan diikuti oleh 101 perempuan, atau 8,85\% dari total 1.140 pendaftar bakal calon kepala daerah. Direktur Eksekutif Perkumpulan untuk Pemilu dan Demokrasi (Perludem) Titi Anggraini menuturkan jumlah ini meningkat -meski tidak signifikan -jika dibanding keterwakilan perempuan dalam dua pilkada sebelumnya. Keterwakilan perempuan hanya 7,47\% dalam Pilkada 2015, dan 7,17\% di Pilkada 2017.

Dalam Pilkada Serentak 2018, ada banyak nama Wanita yang namanya sudah tidak asing lagi baik di Telinga kita maupun di Dunia Politik Indonesia. Khofifah Indar Parawansa, merupakan satu dari dua wanita yang berani untuk maju mencalonkan diri menjadi Calon Gubernur Jawa Timur. Selain beliau, ada juga nama Karolin Margret Natasa yang mencalonkan diri menjadi Calon Gubernur Kalimantan Barat. Mereka adalah 2 dari 49 Wanita yang mencalonkan diri sebagai Calon Kepala Daerah, namun hanya mereka berdua yang mencalonkan diri sebagai Calon Gubernur di daerah masing masing, sedangkan 31 orang mencalonkan diri sebagai Calon Bupati dan 16 lainnya menjadi Calon Walikota. Lalu, dari Total 101 Wanita dalam Pilkada Serentak 2018, 52 sisanya mencalonkan diri sebagai Kepala Daerah dan 5 diantaranya mencalonkan diri menjadi Calon Wakil Gubernur. Ada nama Ida Fauziyah yang mencalonkan diri menjadi Calon Wakil Gubernur Jawa Tengah, lalu ada Chusnunia dari Lampung, Sitti Rohmi Djalilah dari Nusa Tenggara Barat, Emelia Julia Nomleni dari Nusa Tenggara Timur, serta Puti Guntur Soekarno dari Jawa Timur. Selain itu, 28 orang mencalonkan diri jadi wakil bupati dan 18 orang mencalonkan diri jadi wakil wali kota.

Nama yang menarik untuk dibahas ialah Puti Guntur Soekarno, Wanita kelahiran Jakarta pada tanggal 26 Juni 46 tahun silam ini sudah cukup lama mengembara di Dunia Politik Indonesia. Lahir dari keluarga yang memiliki Latar Belakang Politik, membuat Puti turut berkecimpung di Dunia Politik, menyusul jejak karier Tante nya, Megawati Sokearno Putri, dan jejak Kakeknya, Ir. Soekarno. Puti adalah anak dari Guntur Soekarno Putra yang merupakan kakak dari Megawati Soekarno Putri. Aktifitas nya dalam Dunia Politik Indonesia antara lain ialah menjadi Anggota DPR selama 2 Periode, yaitu pada tahun 2009-2014 dan 2014-2019. Pada Pilkada Serentak 2018, Puti Guntur Soekarno maju sebagai Calon Wakil Gubernur Jawa Timur mendampingi Saifullah Yusuf.

Dalam Kegiatan Kampanye nya, Puti kerap melakukan Update Kegiatan Kampanye mya lewat media sosial. Political Marketing yang ia terapkan dalam Kampamye mya sangat terlihat nyata, apalagi ia menggunakan media sosial sebagai penunjang dalam kegiatan Political 
Marketingnya. Political Marketing sendiri secara sederhana ialah aplikasi kegiatan marketing di dalam ruang politik yang umumnya terkonsentrasi pada saat Pemilu atau Pilkada. Dalam kegiatan Political Marketing yang ia lakukan, terselip juga kegiatan Personal Branding yang secara tidak langsung ia lakukan. Personal Branding sendiri merupakan salah satu cara untuk menunjang kegiatan Political Marketing, tentang bagaimana ia ingin terlihat di depan Masyarakat, kalau di media sosial, bagaimana ia ingin terlihat di depan Netizen. Dalam Kegiatan Political Marketing yang ditunjang dengan Kegiatan Personal Branding, media soaial merupakan wadah yang tepat untuk kegiatan tersebut.

Political Marketing sendiri adalah kegiatan Pemasaran Politik yang banyak dilakukan oleh Politisi politisi untuk berkampanye, sebuah wadah yang tepat untuk berkampanye. Sementara Personal Branding ialah teori tentang bagaimana seseorang ingin mempresentasikan dirinya di depan orang banyak. Sebelumnya, sudah ada beberapa penelitian yang menggunakan baik Teori Political Marketing maupun Personal Branding, contohnya adalah Personal Branding Jokowi dalam Media (Analisis Isi Kuantitatif Personal Branding Jokowi dalam Harian Solopos Periode Terbit Maret - Juli 2012) yang dibuat oleh Ana Dwi Iryani.

Lalu, pada penelitian terdahulu, sebagian besar peneliti menggunakan Media Sosial Facebook dan Twitter sebagai sumber penelitian mereka, dan masih jarang peneliti yang menggunakan Instagram sebagai sumber utama Penelitian mereka. Di Indonesia sendiri, pengguna Instagram sendiri tergolong sangat banyak, dilansir dari goodnewsfromindonesia.id, pengguna Instagram di Indoesia saat ini (2018) berjumlah 53.000.000 pengguna, terbanyak ke-3 di dunia, di bawah Amerika Serikat dan Brazil. Namun, di Indonesia pula, Instagram berada diurutan ketiga dalam Most Active Social Media Platforms 2018 yang di buat oleh We Are Social. Untuk rata rata usia dan jenis kelamin, dilansir dari Okezone.com, "Instagrammers mayoritas anak muda, terdidik, dan mapan. Rata-rata mereka berusia 18-24 tahun sebanyak 59 persen, usia 45 34 tahun 30 persen, dan yang berusia 34-44 tahun 11 persen. Pengguna IG perempuan yang paling aktif sebanyak 63 persen dan laki-laki 37 persen," pungkas Paul Webster, Brand Development Lead Instagram APAC.

Itulah alasan mengapa peneliti ingin mengangkat Topik tentang Political Marketing Politisi Perempuan melalui Personal Branding. Terlebih karena Penelitian sebelumnya lebih banyak mengangkat tentang Political Marketing Politisi Laki Laki.

\section{Pertanyaan Penelitian}

"Bagaimana Political Marketing Politisi Perempuan melalui Personal Branding di Media Sosial?" 


\section{TINJAUAN PUSTAKA}

\section{Political Marketing}

O'Shaughnessy (Firmanzah 2008), mengatakan bahwa marketing politik berbeda dengan marketing komersial. Marketing politik bukanlah konsep untuk menjual partai politik atau kandidat kepada pemilih, namun sebuah konsep yang menawarkan bagaimana sebuah parpol atau seorang kandidat dapat membuat program yang berhubungan dengan permasalahan aktual. Di samping itu, marketing politik merupakan sebuah teknik untuk memelihara hubungan dua arah dengan publik. Sehingga politic marketing dalam penelitian ini adalah keseluruhan tujuan dan tindakan strategis dan taktis yang dilakukan oleh aktor politik untuk menawarkan dan menjual produk politik kepada kelompok-kelompok sasaran.

Nimmo (2000) berpendapat bahwa dalam political marketing produk politik terbagi menjadi empat, yaitu 1. Policy; kebijakan, isu, dan program kerja, 2. Person; figur kandidat dan figur pendukung, 3. Party; ideologi, struktur, visi-misi dari partai yang mencalonkan, 4. Presentation; medium komunikasi atau konteks simbolis Keempat produk politik tersebut harus ada dalam political marketing, sebab kandidat yang melakukan political marketing tetapi tanpa memiliki program kerja,

\section{Political Marketing melalui Media Sosial}

Media sosial tak hanya sebagai alat untuk bersosialisasi atau pemasaran secara online namun bisa di manfaatkan sebagai alat politik untuk berkampanye. Hal itu juga bisa dilihat dari kemenangan Barack Obama sebagai Presiden Amerika Serikat dalam dua periode karena dibantu dengan jejaring sosial seperti Twitter, blog, dan Facebook. Terpilihnya Obama sebagai Presiden AS tidak lepas dari upaya tim suksesnya yang menggunakan strategi berkampanye melalui internet. Selain untuk menggalang dukungan suara teryata kampanye online yang dilakukan oleh tim sukses Obama adalah untuk mendulang dana dari masyarakat. Terbukti kampanye melalui internet dan jejaring sosial sangat efektif dan berpengaruh luas (Antara Sumsel). 
Penggunaan media sosial di Indonesia sebagai media political branding sudah digunakan tetapi sebagai pelengkap. Gerakan atau kegiatan politik dengan memanfaatkan sosial media juga kini banyak digunakan oleh para politisi, seperti pada saat pilkada di Jakarta beberapa waktu lalu yang akhirnya dimenangkan oleh Jokowi dan Ahok. Kemenangan tersebut juga ditunjang dengan handalnya kampanye di sosial media.

Kini, para politisi mulai melek untuk memanfaatkan media sosial apalagi menjelang Pemilu Legislatif dan Pemilu Presiden pada 2014. Ini dibuktikan dengan petinggi-petingggi partai seperti Presiden Susilo Bambang Yudhoyono yang juga Ketua Umum DPP Partai Demokrat, Sekjen Partai NasDem Patrice Rio Capella dan politisi lainnya. Mereka dituntut untuk bisa menjalin hubungan lebih dekat dengan rakyat melalui jejaring sosial. Partai NasDem yang dipimpin Surya Paloh juga mengandalkan media sosial untuk memperluas jaringan dan menyos

\section{Teori Retorika Aristoteles}

Menurut Aristotle, makna tersedia dari persuasi ada dua; Inartistic proofs yaitu bukti esensial yang tidak dibuat speaker, contohnya testimoni saksi, dokumen, dan Artistic proofs yaitu bukt internal yang dibuat speaker, yakni logical atau logos yaitu argumen dalam speech, ethical atau ethos yaitu cara etika speaker terlihat saat speech, dan emotional atau pathos yaitu perasaan speech yang tergambar oleh pendengar.

\section{Bukti Logis: Baris Argumen yang Masuk Akal}

Logos adalah bukti logis yang muncul dari argumen dalam speech. Ada dua bentuk logos, yakni enthymeme dan example. Enthymeme yaitu versi inkomplit dari silogisme deduktif formal yang dibuat dengan hilangkan premis yang sudah diterima atau kesimpulan yang sudah jelas.

Walaupun tanpa adanya premis major (premis yang sudah diterima), pendengar dapat membayangkannya dengan vivid.

\section{Bukti Etis: Sumber Kredibilitas yang Dirasakan}

Ethos adalah kredibilitas yang dirasakan yang datang dari intellegence, karakter dan niat baik speaker pada audiens yang terungkap lewat pesan yang disampaikan. 
Ada 3 kualitas yang membangun skior untuk kredibilitas tinggi:

Intellegence, yaitu kesamaan ide speaker dengan kepercayaan audiens.

Character (karakter), yaitu pengaruh pada imej speaker sebagai orang yang baik dan jujur.

Goodwill (niat baik), yaoti intensi atau niat speaker pada audiens dinilai dengan baik.

\section{Bukti Emosional: Menyerang Nada Responsif}

Pathos adalah bukti emosional atau perasaan pendengar, atau bagaimana speaker membuat audiens merasakan apa yang disampaikan.

- Kemarahan vs. Kelembutan

- Cinta atau pertemanan vs. Kebencian

- Ketakutan vs. Kepercayaan diri

- Kejengkelan vs. Rasa kasihan

- Kekaguman vs. Kedengkian

\section{METODOLOGI PENELITIAN}

Penelitian ini menggunakan metode penelitian kualitatif deskriptif dengan teknik analisa Semiotika Roland Barthes. Roland Barthes menyatakan bahwa semiologi adalah tujuan untuk mengambil berbagai sistem tanda seperti substansi dan batasan, gambar-gambar, berbagai macam gesture, berbagai suara music, serta berbagai obyek, yang menyatu dalam system of significance. Lagi, menurut Roland Barthes, semiotika memiliki beberapa konsep inti, yaitu signification, denotation dan connotation, dan meta language atau myth.

Signification, menurut Barthes, signification dapat dipahami sebagai sebuah proses yang berupa tindakan, yang mengikat signifier dan signified, dan yang menghasilkan sebuah tanda. Dalam proses tersebut, dua bagian dari sebuah tanda tergantung satu sama lain dalam arti bahwa signified diungkapkan melalui signifier, dan signifier diungkapkan dengan signified. Misalnya, kata "kucing". Ketika kita mengintegrasikan signifier 
"kucing" dengan signified "hewan berkaki empat yang mengeong", maka bahasa tanda "kucing" pun muncul. Proses ini disebut sebagai signification atau sebuah sistem signifikasi.

Denotation Dan Connotation, Dalam semiotika, denotation dan connotation adalah dua istilah yang menggambarkan hubungan antara signifierdan signified. Selain itu, denotation dan connotation juga menggambarkan sebuah perbedaan analitis yang dibuat antara dua jenis signified yaitu denotative signified dan connotative signified (Chandler, 2007). Denotation danconnotation selalu digambarkan dalam istilah level of representation atau level of meaning. Dalam bukunya yang berjudul Elements of Semiology(1964), Roland Barthes membedakan denotation dan connotationdengan merujuk pada pendapat Louis Hjelmslev dengan menggunakan istilah orders of signification. Pada tingkatan ini terdapat sebuah tanda yang terdiri atas sebuah signifier dan sebuah signified. Dalam artian, denotation merupakan apa yang kita pikirkan sebagai sebuah literal, bersifat tetap, dan memiliki makna kamus sebuah kata yang secara ideal telah disepakati secara universal. Sedangkan, connotation adalah order of signification yang kedua yang berisi perubahan makna kata secara asosiatif. Menurut Barthes, hal ini hanya berlaku pada tataran teoritis. Pada tataran praktis, membatasi makna ke dalam sebuah denotative akan sangat sulit karena tanda selalu meninggalkan jejak makna dari konteks sebelumnya. Dalam penelitian ini peneliti melakukan analisa semiotika terhadap foto-foto dalama kun instagram sebatas hingga petanda (signifier) dan penanda (signified)

\section{Unit Analisis}

Selama masa kampanye Puti Soekarno, beliau beberapa kali menunggah aktifitas nya di Instagram, dalam Rentang waktu 5 Bulan (FebruariJuni) Beliau telah menunggah beberapa foto, penulis pun memilih foto dengan jumlah likes terbanyak dalam waktu itu (Februari-Maret)

\section{PEMBAHASAN \& DISKUSI}

Penggunaan media sosial untuk kampanye politik kini sudah begitu gencar dilakukan oleh para politisi untuk meraih simpati dari calon konstituen mereka. Lewat media sosial, seorang politikus bisa langsung menyapa para konstituennya tanpa harus memandang jauhnya jarak. 
Bentuk tampilan instagram yang seperti album foto tersebut membuat penggunanya dapat menikmati sajian foto dengan lebih detail dibandingkan tampilan foto di akun Facebook. Selain itu perbedaan Instagram dengan media sosial lainnya semisal Twitter adalah penonjolan pada foto, selain foto kekuatan pesan dalam postingan Instagram terletak pula pada kata-kata yang ditulis pada caption foto.

Pilihan foto yang diunggah ke akun Instagram dapat membantu menciptakan kesan tertentu yang ingin dibentuk oleh figur politisi. Sekarang ini hampir setiap politisi memiliki akun Instagram yang dapat diakses dengan mudah oleh masyarakat. Sebagian dari mereka mengelola akun tersebut dengan bantuan tim administrasi, sebagian lainnya mengerjakan sendiri akun Instagram tersebut. Seperti telah dijelaskan pada bab pendahuluan, penelitian ini ingin melihat unsur political marketing apa yang paling menonjol yang digunakan oleh Puti Soekarno dalam bertarung di ajang Pilkada 2018 dan gaya retorika apa yang ia gunakan untuk mendukung political marketing-nya. Untuk menjawab kedua pertanyaan tersebut peneliti menggunakan metode analisis semiotika agar dapat menjelaskan secara rinci.

Tabel 1: Kategori Political Marketing

\begin{tabular}{|c|c|c|}
\hline No & Kategori & Keterangan \\
\hline 1 & Policy & Kebijakan, isu, dan program kerja \\
\hline 2. & Person & Figur kandidat dan figur pendukung \\
\hline 3. & Party & Ideologi, struktur, visi-misi dari partai yang mencalonkan \\
\hline 4. & Presentation & Medium komunikasi atau konteks simbolis \\
\hline
\end{tabular}

Tabel 2: Metode Semiotika pada foto di akun Instagram @ putisoekarno dan Analisis Political Marketing serta Retorika Aristoteles

\begin{tabular}{|c|c|c|c|c|c|c|c|}
\hline \multicolumn{5}{|c|}{ Petanda (Semiotika) } & \multirow{2}{*}{$\begin{array}{c}\text { Penanda } \\
\text { (Semiotika) }\end{array}$} & \multirow{2}{*}{$\begin{array}{c}\text { Unsur Political } \\
\text { Marketing }\end{array}$} & \multirow{2}{*}{$\begin{array}{c}\text { Retorika } \\
\text { Aristoteles }\end{array}$} \\
\hline Visual & Caption Foto & $\begin{array}{l}\text { Angle } \\
\text { Kamera }\end{array}$ & $\begin{array}{l}\text { Tata } \\
\text { Cahaya }\end{array}$ & Warna & & & \\
\hline
\end{tabular}




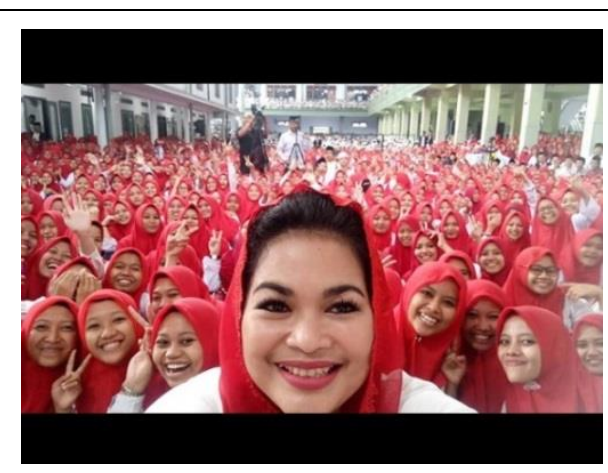

Foto 1

Februari 2018

Jumlah "love": 3,651

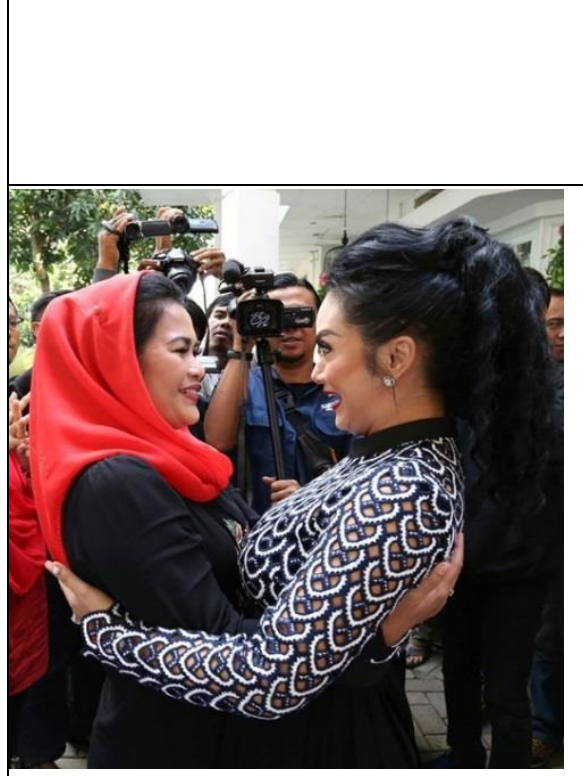

Foto 2

Februari 2018

Jumlah "love" 3,543
"Ketemu adek-adek

jaman now di

Pesantren Al Falah

Ploso.

Alhamdulillah

disambut baik.

Senang sekali melihat

adek-adek ceria.

Semoga jadi anak soleh soleha, kelak menjadi manusia

unggul yang

mengguncang Jawa

Timur.

Ngomong-ngomong ini keren sekali adekadek dengan pakaian nuansa merah".

Di tengah kesibukan, disempatin mampir ke Malang ketemu sahabat, KD.

Selamat atas peresmian toko

Makobu cakenya ya

@ krisdayantilemos

@ makobucake

\begin{tabular}{|c|c|c|c|c|c|c|}
\hline $\begin{array}{l}\text { Close Up, } \\
\text { Eye Level }\end{array}$ & $\begin{array}{l}\text { High } \\
\text { Key }\end{array}$ & $\begin{array}{l}\text { Dominasi } \\
\text { warna merah } \\
\text { dan putih }\end{array}$ & $\begin{array}{l}\text { Caption foto } \\
\text { menjelaskan } \\
\text { tentang kunjungan } \\
\text { Puti ke sebuah } \\
\text { pesantren di Jawa } \\
\text { Timur. Puti } \\
\text { tampak } \\
\text { menggunakan } \\
\text { pilihan kata yang } \\
\text { sedang populer di } \\
\text { kalangan remaja } \\
\text { "jaman nowIa } \\
\text { juga memuji para } \\
\text { siswi pesantren } \\
\text { yang } \\
\text { menggunakan } \\
\text { warna merah yang } \\
\text { sama dengan } \\
\text { lambang PDIP.. }\end{array}$ & $\begin{array}{ll}\text { 1) } & \text { Person } \\
\text { 2) } & \text { Party }\end{array}$ & $\begin{array}{l}\text { 1) } \\
\text { 2) }\end{array}$ & $\begin{array}{l}\text { Ethos } \\
\text { Pathos }\end{array}$ \\
\hline $\begin{array}{l}\text { Medium } \\
\text { Close Up, } \\
\text { Eye Level }\end{array}$ & $\begin{array}{l}\text { High } \\
\text { Key }\end{array}$ & $\begin{array}{l}\text { Dominasi } \\
\text { hitam dan } \\
\text { merah }\end{array}$ & $\begin{array}{l}\text { Informasi pada } \\
\text { foto dan caption } \\
\text { menunjukkan } \\
\text { kedekatan Puti } \\
\text { dengan salah } \\
\text { eorang Diva } \\
\text { Indonesia yaitu } \\
\text { Krisdayanti. } \\
\text { Pengambilan } \\
\text { gambar medium } \\
\text { close up } \\
\text { menunjukkan } \\
\text { bahwa Puti ingin } \\
\text { terlihat dekat dan } \\
\text { akrab dengan } \\
\text { followersnya. }\end{array}$ & $\begin{array}{ll}1) & \begin{array}{l}\text { Figur } \\
\text { pendukung } \\
\text { (Person) }\end{array} \\
\text { 2) } & \text { Figur } \\
& \text { kandidat } \\
& \text { (Person) }\end{array}$ & $\begin{array}{l}\text { 1) } \\
\text { 2) }\end{array}$ & $\begin{array}{l}\text { Ethos } \\
\text { Pathos }\end{array}$ \\
\hline
\end{tabular}




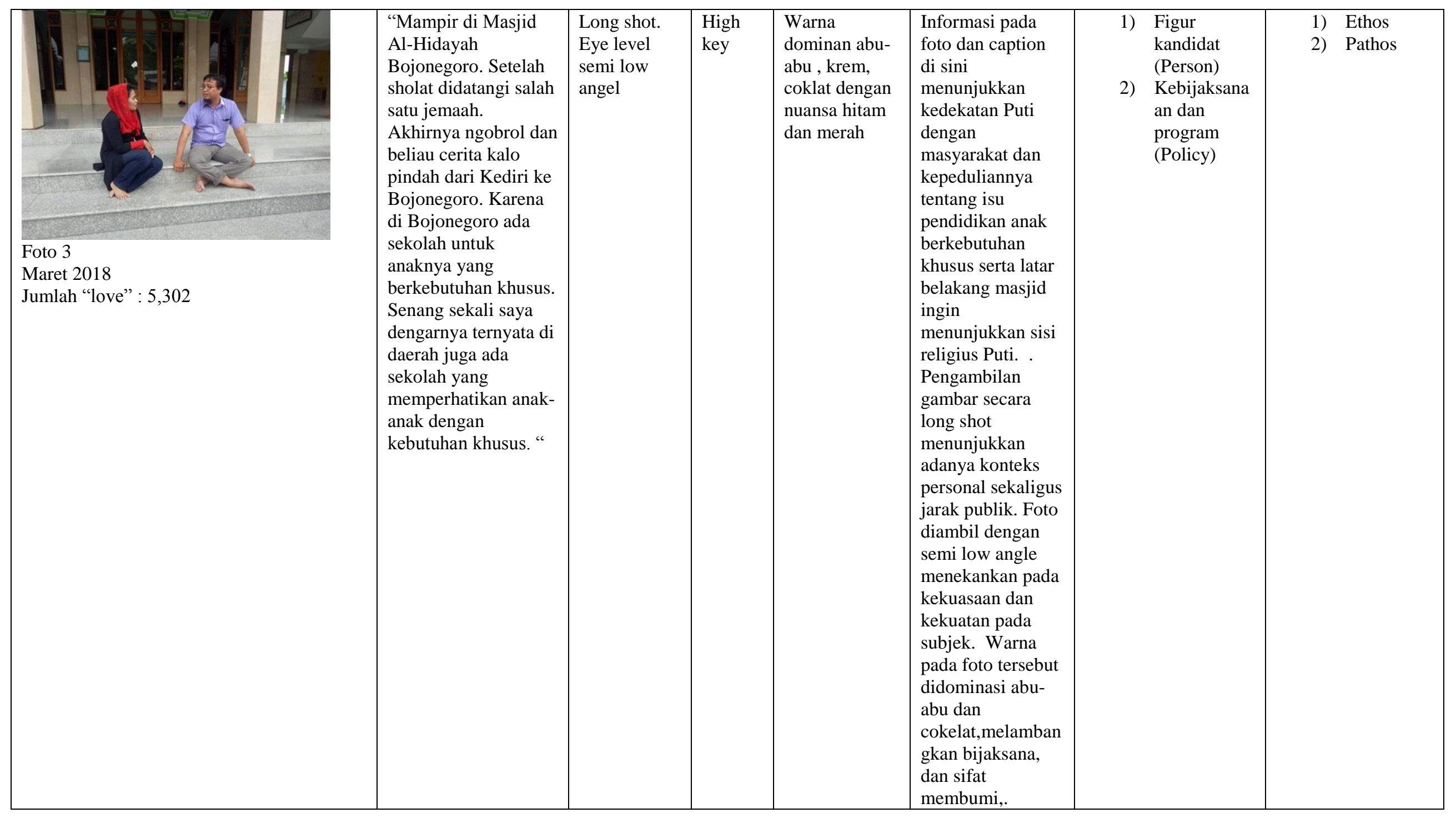




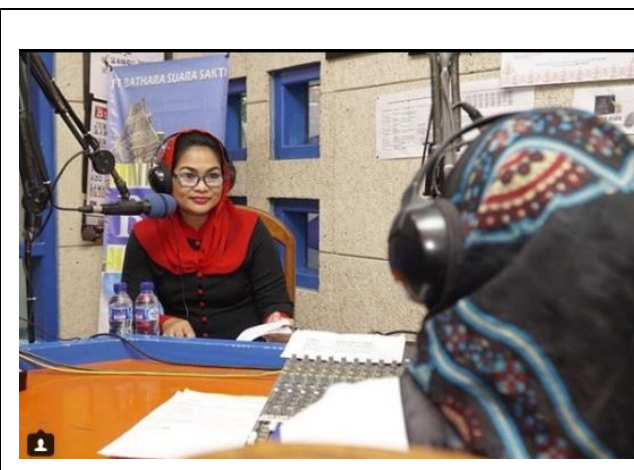

Foto 4

Maret 2018

Jumlah "love" : 4,761

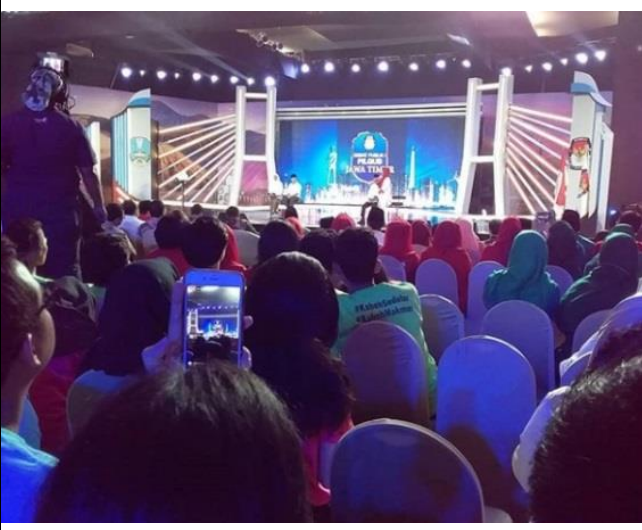

Foto 5

April, 2018

Jumlah "love" 6,463
Menyapa warga

Bojonegoro melalui

Radio BaSS

FM..Seru deh..Udah

cocok beum saya jadi

penyiar radio?

(emotikon tertawa)

\#radiobassfmbojoneg

oro

\#bojonegoro

\#GuspulMbakPuti

\#JatimSedulur

\#KabehSedulur

\#KabehSedulurKabeh

Makmur

\section{"Doakan}

@gusipul_id dan

saya

ya.\#kabehmakmur\#g

usipulmbakputi\#jatim

hebat\#debatpilgubjati

$\mathrm{m}$ "

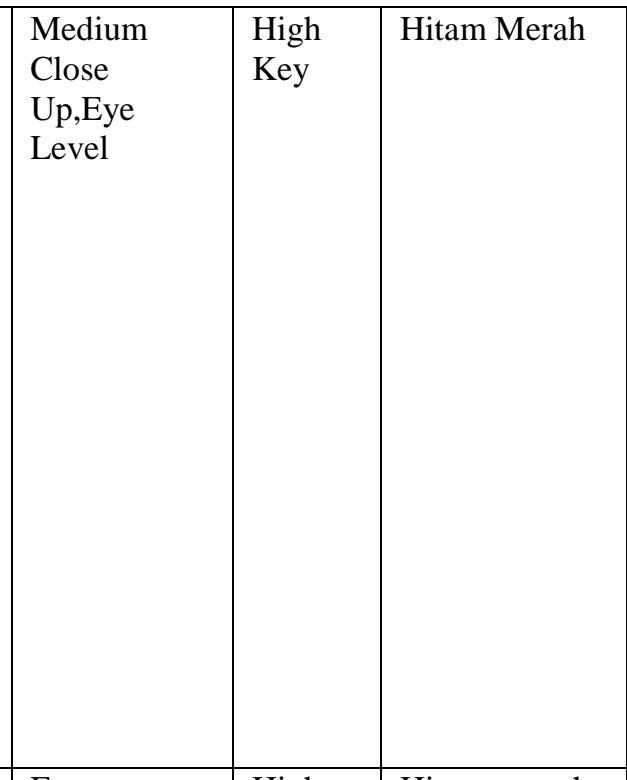

Extreme

long shot,

eye level
Hitam, merah,

Key

putih

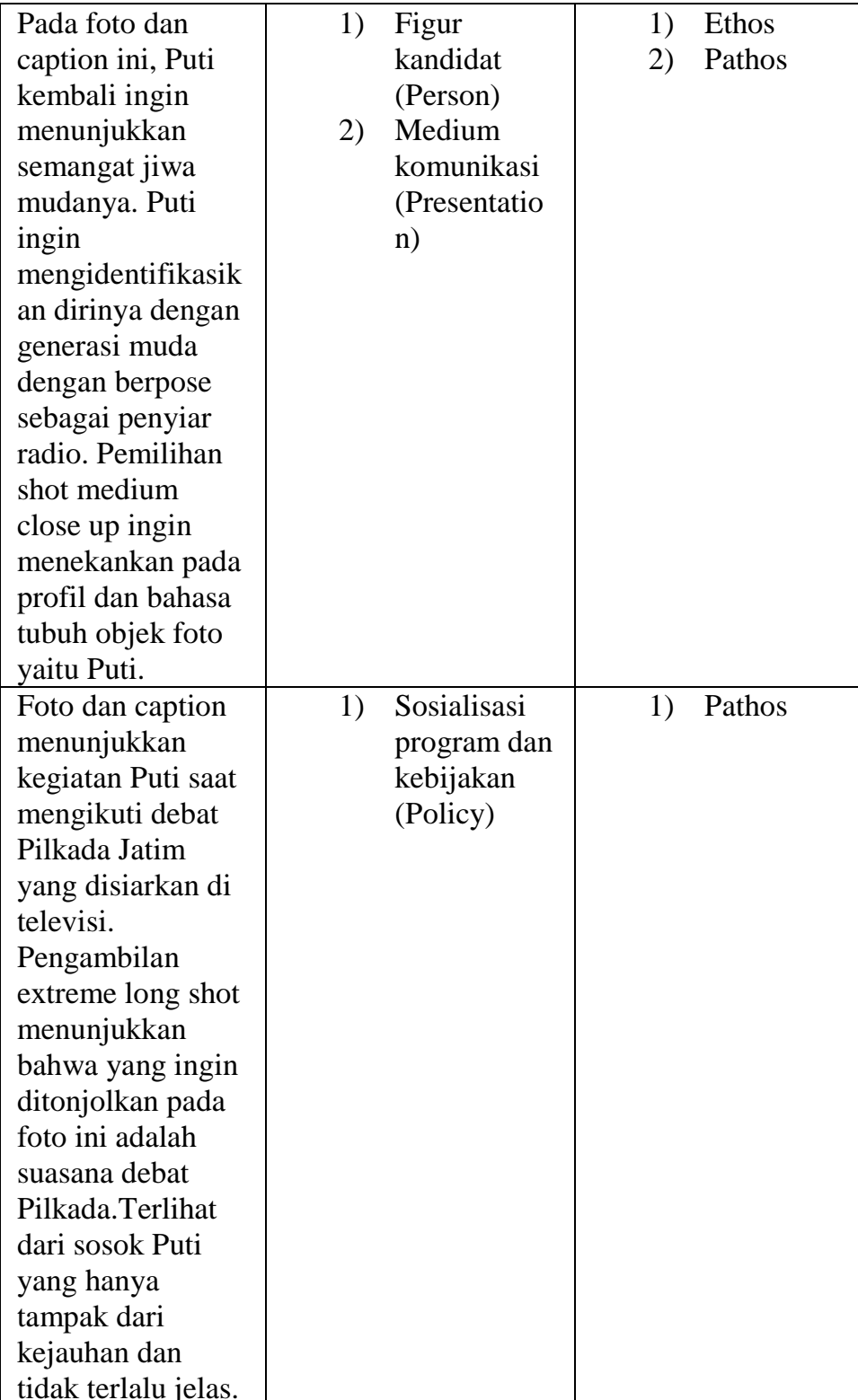




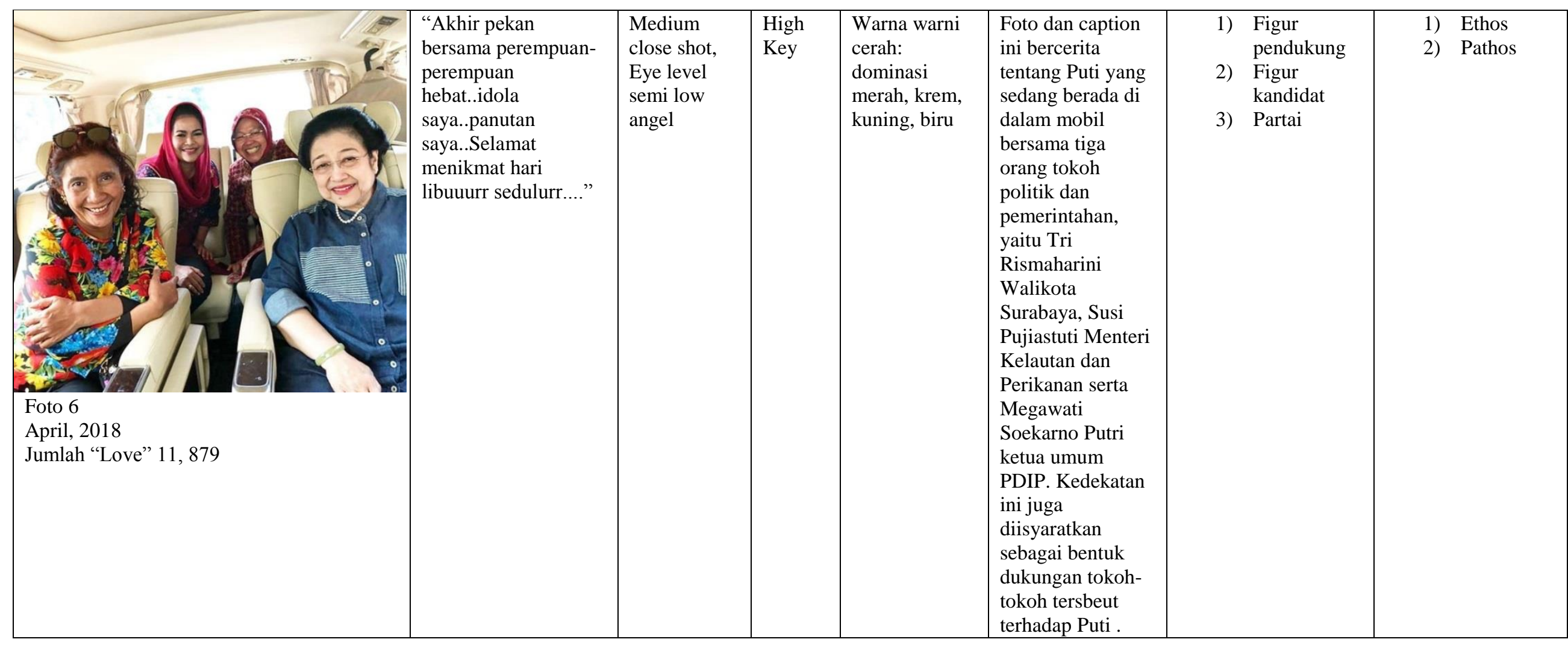




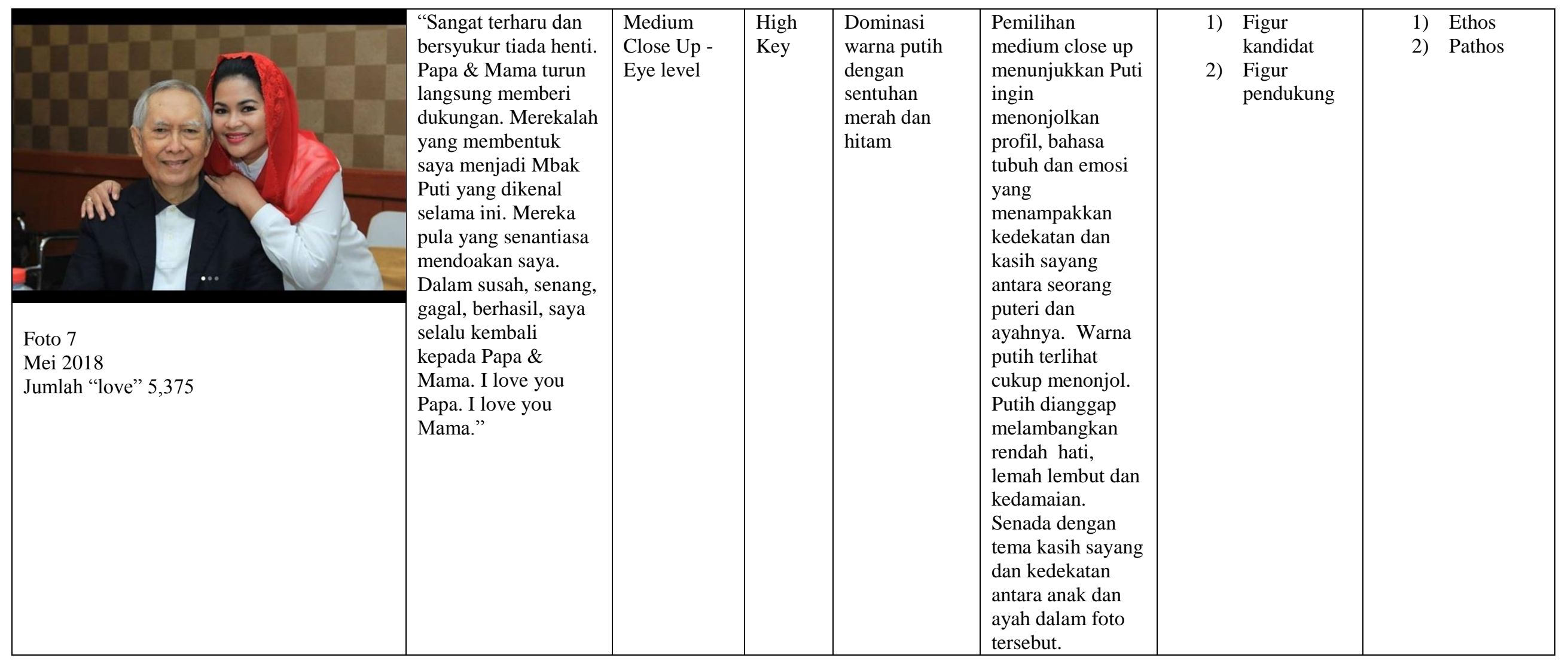




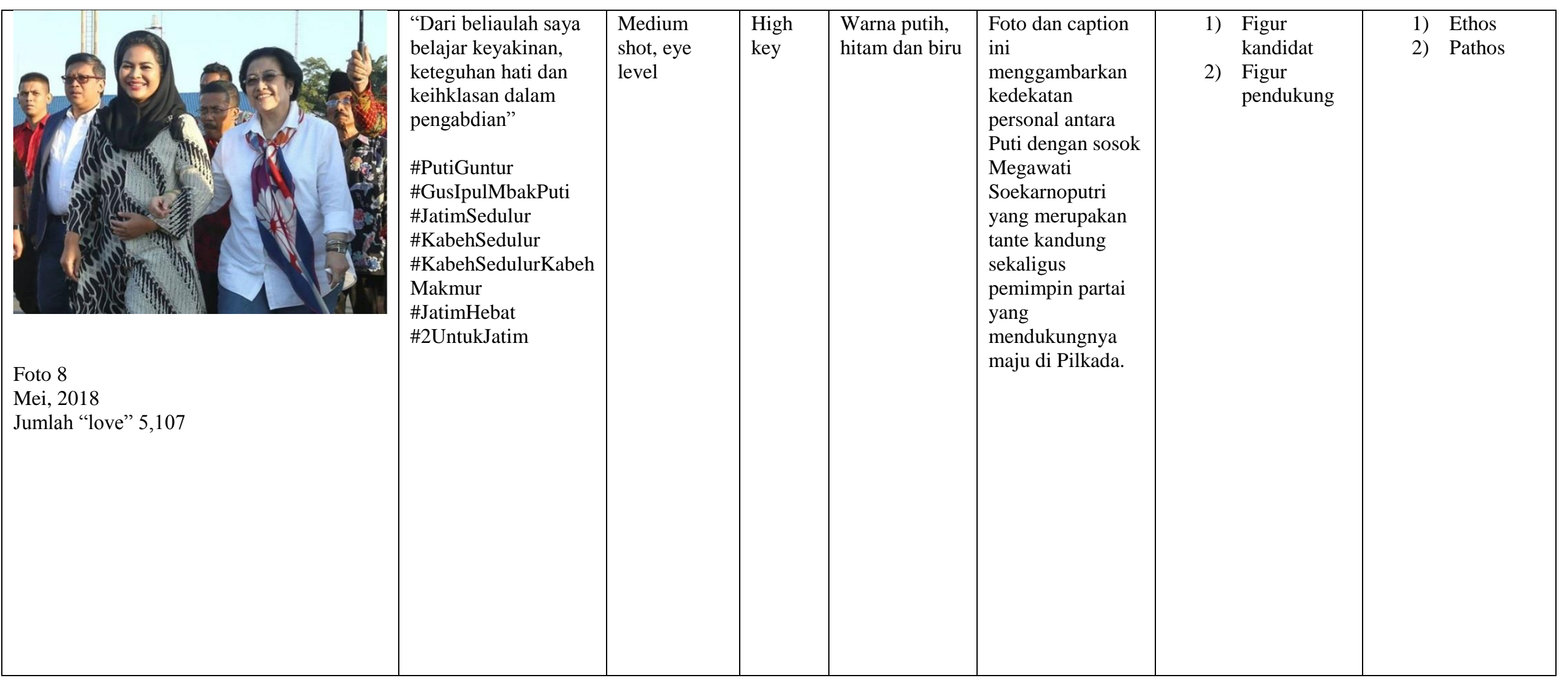




\begin{tabular}{|c|c|c|c|c|c|c|c|c|}
\hline$\frac{2}{2} \frac{A S A}{2}$ & $\begin{array}{l}\text { "Semangat } \\
\text { kebersamaan. } \\
\text { Persaudaraan religius } \\
\text { - nasionalis - } \\
\text { Sukarnois - } \\
\text { Nahdliyin" }\end{array}$ & $\begin{array}{l}\text { Medium } \\
\text { Close Shot. } \\
\text { High Level }\end{array}$ & $\begin{array}{l}\text { High } \\
\text { key }\end{array}$ & $\begin{array}{l}\text { Dominasi } \\
\text { Putih, Hitam } \\
\text { dan Merah }\end{array}$ & $\begin{array}{l}\text { Informasi dalam } \\
\text { foto dan caption } \\
\text { menunjukkan } \\
\text { keragaman latar } \\
\text { belakang partai } \\
\text { pendukung } \\
\text { pasangan Gus } \\
\text { Ipul dan Puti } \\
\text { Soekarno, } \\
\text { Pengambilan } \\
\text { gambar secara } \\
\text { high level yang } \\
\text { membuat objek } \\
\text { foto menjadi } \\
\text { tampak lebih kecil } \\
\text { menunjukkan } \\
\text { ketidakberdayaan. } \\
\text { Foto ini diambil } \\
\text { di penghujung } \\
\text { kampanye } \\
\text { menjelang Pilkada } \\
\text { langsung. Kali ini } \\
\text { Puti tampak } \\
\text { berbeda dengan } \\
\text { menggunakan } \\
\text { kerudung hijau. } \\
\text { Hijau bisa jadi } \\
\text { melambangkan } \\
\text { warna salah satu } \\
\text { partai } \\
\text { pendukungnya } \\
\text { yaitu PKB }\end{array}$ & $\begin{array}{l}1 \\
2 \\
3\end{array}$ & $\begin{array}{l}\text { Figur } \\
\text { Kandidat } \\
\text { Figur } \\
\text { Pendukung } \\
\text { Partai }\end{array}$ & $\begin{array}{ll}\text { 1) } & \text { Ethos } \\
\text { 2) } & \text { Pathos } \\
\end{array}$ \\
\hline
\end{tabular}




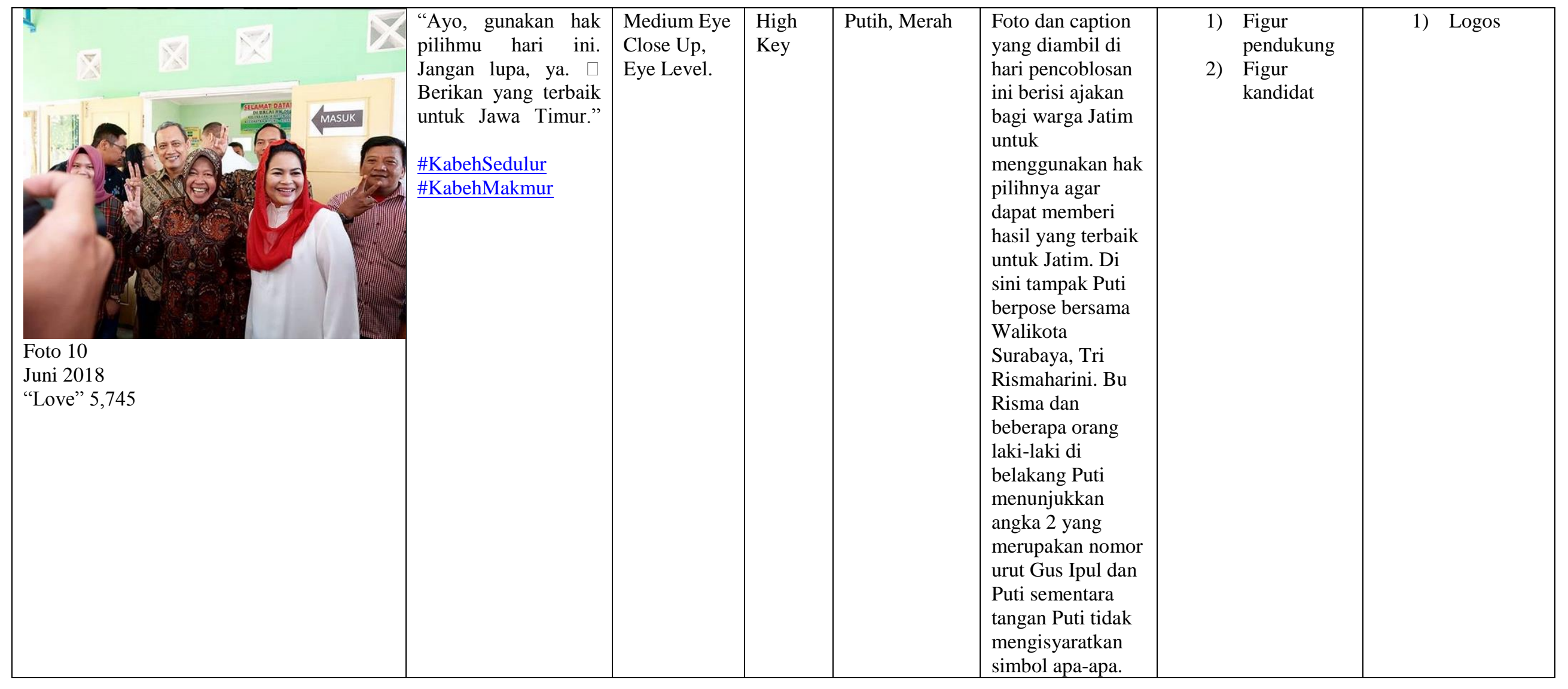

Berikut pembahasan terperinci mengenai kaitan antara temuan berdasarkan metode analisa semiotika dengan unsur political marketing dan unsur Retorika Aristoteles pada foto-foto di akun Instagram @ putisoekarno dalam kurun waktu kampanye Pilkada (Februari - Juni 2018) :

Foto 1: Pada foto ini Puti tampak sedang berfoto bersama para siswi pesantren. Melihat foto tersebut setidaknya ada beberapa unsur dari political marketing yang ingin Puti tonjolkan, yaitu Policy, Person dan Party. Di sini Puti menunjukkan kepeduliannya terhadap bidang pendidikan yang merupakan salah satu program kerja unggulannya (policy). Kedekatan yang digambarkan bersama dengan para siswi pesantren 
menunjukkan figur (person)Puti yang dekat dengan generasi muda. Sebutan "adek-adek jaman now" menunjukkan keinginan Puti untuk mendekatkan "jarak" usia dengan para siswi pesantren (yang sebenarnya jika dilihat secara umur lebih pantas diebut "anak-anak" dibanding “adek-adek"). Penggunaan pilihan kata "jaman now" juga ingin memperlihatkan bahwa Puti adalah figur kandidat yang berjiwa muda dan mengikuti trend pergaulan remaja saat ini. Lalu di akhir caption Puti memuji kerudung para siswi pesantren yang kompak berwarna merah. Merah dianggap mewakili warna partai pengusung Puti yaitu PDIP. Hal ini menunjukkan betapa Puti sangat ingin menonjolkan identitas partai pada foto-foto di Instagramnya (party). Puti pun hampir selalu mengenakan kerudung berwarna merah di setiap foto yang ia unggah di akun IG nya.

Sementara itu dilihat dari teori Retorika Aristoteles, pada foto ini Puti tampak mengedepankan Ethos dan Pathos. Ethos diperlihatkan dengan harapan dan doa yang ia tujukan untuk para siswi pesantren agar tumbuh menjadi "generasi muda soleh, soleha, pribadi yang unggul dan menguncang Jawa Timur.” Melalui ungkapan doa dan harapan tersebut Puti menunjukkan niat baik dan tulusnya (Ethos/Karakter yang baik). Sementara itu pilihan kata yang menggambarkan kedekatan dirinya dengan generasi muda menonjolkan sisi Pathos yang berarti membangkitkan emosi followers. Emosi yang ingin Puti bangkitkan di sini adalah keramahan dan persahabatan. Puti ingin mendekatkan diri dengan konstituennya melalui karater dan ucapan yang baik sehingga meggugah sisi emosional konstituennya.

Foto2 : Di foto ini Puti berpose bersama salah seorang penyanyi papan atas Indonesia yaitu Krisdayanti. Pada caption, Puti menuliskan bahwa ia menyempatkan diri untuk bertemu "sahabat" (Krisdayanti). Di sini unsur political marketing yang tampak menonjol adalah figur kandidat dan pendukung. Puti sebagai kandidat digambarkan sebagai sosok yang memiliki pergaulan yang luas hingga ke kalangan selebritis. Caption yang menyebutkan "menyempatkan untuk bertemu sahabat" juga menunjukkan Puti adalah figur politisi yang setia kawan, bahkan ia membantu Krisdayanti mempromosikan toko kuenya yang berada di Malang dengan menyebutkan akun instagram toko kue milik Krisdayanti. Dengan menmajang foto Krisdayanti di dalam akun Instagramnya di masa kampanye, Puti seolah ingin menunjukkan bahwa sosok Krisdayanti adalah salah satu pendukungnya. Di sini ia ingin menekankan figur pendukung (Person). Tidak lupa nuansa hitam dan merah yang tampak pada busana yang dikenakan Puti dan Krisdayanti senada dengan warna logo partai PDIP. 
Dari pilihan kata yang digunakan oleh Puti di caption foto ini, sekali lagi unsur Ethos dan Pathos yang ingin ia tonjolkan. Figur setia kawan, hangat dan bersahabat merupakan bagian dari karakter baik dari seorang komunikator (Ethos) yang kerap digunakan untuk meraih simpati lawan bicara. Kemudian, dari karakter baik yang ia tonjolkan tersebut maka sisi emosional dari followers yang ingin digugah adalah rasa persahabatan. Keluwesan Puti untuk bergaul dapat menyentuh sisi emosional followers yang menangkap gambar tersebut sebagai bukti bahwa Puti adalah sosok yang hangat dan dapat menawarkan persahabatan kepada berbagai kalangan.(Pathos).

\section{Foto 3 :}

Pada foto ini Puti tampa sedang berbincang dengan salah seorang warga Jawa Timur dengan latar belakang teras sebuah Masjid di Bojonegoro. Nuansa figur kandidat tampak menonjol di sini. Puti terlihat mengobrol akrab dengan si bapak bahkan sampai bapak tersebut menceritakan alasannya pindah ke Bojonegoro (dari Kediri). Puti yang duduk di teras dan mau mendengarkan kisah si bapak menunjukkan kesan pemimpin yang merakyat dan tidak berjarak dengan masyarakat. Latar belakang masjid juga merupakan upayanya untuk menunjukkan kesan religius dan kedekatan dengan umat Muslim. Warna warni yang ditampilkan pada foto tersebut juga cenderung netral dan lembut. Seperti yang sudah disebutkan pada tabel analisis semiotika di atas, warna abu-abu dan coklat melambangkan kebijaksanaan, keteduhan dan rasa rendah hati serta membumi. Kesatuan warna pada foto mendukung kesan yang ingin ditonjolkan. Selain menunjukkan figur kandidat (Person), foto tersebut juga berbicara tentang bidang yang menjadi fokus dan perhatian Puti yaitu anak-anak dan pendidikan. Walaupun ia tidak berbicara banyak tetang rencananya di bidang pendidikan pada caption ini, ungkapan yang dituliskan pada caption cukup menunjukkan kepedulianny pada dunia anakanak dan pendidikan. Maka ini erat kaitannya dengan unsur Policy (program-program dan kebijakan-kebijakan) dalam Political Marketing.

Dalam menonjolkan sisi figur dan kebijakannya, Puti menggunakan pilihan kata yang juga sederhana dan membumi. Kembali lagi ia menggunakan unsur Ethos dan Pathos untuk meraih simpati dari followers. Dari sisi Ethos ia berusaha menunjukkan karakternya yang peduli dan tidak berjarak dengan rakyat. Puti mau duduk di lantai bersebelalahan dengan salah seorang jemaah masjid, bahkan berbincang-bincang hingga ia tahu latar belakang orang tersebut. Puti juga menampakkan kebanggaannya dengan daerah Bojonegoro yang dinilai cukup maju dan sensitif dalam memfasilitasi pendidikan anak-anak berkebutuhan khusus. Niat dan karakter baik (Ethos) yang ditunjukkan dalam foto tersebut 
adalah upaya untuk menggugah sisi emosional persahabatan dan kasih sayang dari sudut pandang followers (Pathos). Kepedulian pada masyarakat, keinginan untuk mendengar cerita warga dan kemampuan untuk mengapresiasi kemajuan suatu daerah ditunjukkan melalui foto ini.

\section{Foto 4:}

Foto dan caption ini bercerita tentang kegiatan Puti melakukan sosialisasi di radio Bass FM di Bojonegoro. Seperti yang peneliti jelaskan pada bagan, Puti menggunakan pengambilan gambar medium shot eye level untuk menunjukkan kedekatan dengan followers. Ia ingin tampak dekat dengan masyarakat. Kemudian ketika ia menuliskan "sudah cocok kan jadi penyiar radio?" dan diikuti dengan emotion icon tertawa menunjukkan ia sedang berkelakar. Dari foto ini Puti tampak ingin terlihat seperti anak muda, dengan mengunjungi radio dna berpose seperti penyiar radio. Unsur figur kandidat (Person) terlihat paling menonjol pada foto ini. Selain itu, seperti biasa, Puti selalu mengenakan busana bernuansa hitam dan merah yang menunjukkan identitas partai pendukungnya yaitu PDIP. Selain unsur figur kandidat dan partai, unsur lainnya yang tampak adalah medium yang digunakan untuk berkomunikasi dengan konstituennya (Presentation). Di sini terlihat bahwa selain menggunakan media sosial untuk berinteraksi dengan followers, Puti juga tetap menggunakan media konvensional yaitu radio. Foto ini menunjukkan bahwa medium komunikasi yang digunakan oleh Puti dalam berkampanye beragam, bukan hanya media sosial namun media konvensional tetap tidak dilupakan.

Dari segi retorika, pada foto ini Puti menunjukkan karakternya yang senang bercanda dan ramah. Hal tersebut ditunjukkan dengan caption nya yang diikuti dngan emotion icon setelah ia menanyakan pada followers nya apakah ia sudah cocok menjadi penyiar berita. Karakter yang hangat dan bersahabat itu mencerminkan unsur Ethos. Sedangkan kemampuan Puti untuk mendekatkan diri dengan masyarakat dan menciptakan suasana yang akrab menonjolkan sisi Pathos dalam kerangka retorika Aristoteles.

\section{Foto 5:}

Foto dan caption ini terbilang sederhana dibanding foto lainnya namun tetap menuai banyak tanda "love" dari para followers Puti. Foto yang diambil secara long shot ini menunjukkan suasana debat pilkada Jatim dan diambil dari sudut pandang penonton. Bagian yang lebih terlihat 
dominan adalah keramaian penonton (pendukung Gus Ipul dan Puti). Sosok Puti sendri tampak begitu jauh dan kecil. Sehingga yang ingin ditonjolkan di sini adalah kegiatan debat itu sendiri. Maka unsur Political Marketing yang tampak dominan di sini adalah Policy , artinya pada kesempatan debat tersebut Puti mendapat panggung untuk memperkenalkan diri sekaligus program serta kebijakannya kepada khalayak luas. Terlebih lagi acara tersebut ditampilkan secara live di stasiun TV nasional. Namun hal yang disayangkan adalah mengapa tidak menunjukkan foto ketika Puti sedang berargumen dan kemudian diikuti dengan caption yang senada dengan pembicaraan Puti di momen debat Pilkada. Hal tersebut dapat lebih "menjual" sosok figur Puti sebagai kandidat Cawagub dibandingkan sekedar foto suasana debat dan caption yang memohon doa kepada para followers nya.

Secara Retorika Aristoteles, tidak terlalu tampak unsur yang ingin ditampilkan oleh Puti melalui pilihan kata maupun gambar. Hal yang paling mendekati adalah sisi emosi (Pathos) yang ingn digugah karena Puti menunjukkan kerendahatiannya untuk meminta doa dari para followers nya sebelum ia mengikuti debat kandidat Cagub Cawagub Jatim. Itu menunjukkan Puti sangat membutuhkan dukungan followers dan pendukungnya agar ia dapat menjalani acara dengan lancar.

\section{Foto 6:}

Foto ini merupakan salah satu foto yang memiliki "love" terbanyak sepanjang masa kampanye Pilkada 2018 di akun IG milik Puti. Dalam foto ini Puti berada di tengah-tengah ketiga tokoh besar lainnya, yaitu Tri Rismaharini, Susi Pudjiastuti dan Megawati Soekarnoputri. Unsur political marketing yang tampak menonjol di sini adalah figur kandidat dan pendukung (Person) serta figur partai (Party). Pada foto tersebut Puti digambarkan sebagai sosok yang memiliki jejaring pergaulan yang luas. Kedekatannya dengan sosok-sosok ternama di bidang pemerintahan dan politik diharapkan dapat mendongkrak popularitas Puti sebagai calon wakil Gubernur Jawa Timur. Ketiga sosok yang berada di foto bersama Puti memiliki kelebihan dan prestasinya masing-masing serta telah dikenal baik oleh masyarakat se-Indonesia. Kebersamaan mereka di dalam foto tersebut juga secara tersirat menggambarkan dukungan kepada Puti dalam Pilkada 2018 ini. Sebagai kandidat Cawagub, Puti ingin menggunakan ketenaran para tokoh di foto tersebut untuk meningkatkan popularitasya. Adapun figur parta di sini ditunjukkan dengan keberadaan Megawati Sukarno Putri sebagai ketua umum PDIP sekaligus merupakan tante langsung dari Puti. Unsur partai juga ditegaskan kembali melalui pilihan busana yang dikenakan Puti yaitu busana bernuansa merah dan hitam. 
Sementara itu dilihat dari retorika yang ia gunakan dalam caption, Puti tampak menggunakan bahasa yang santai. Pemilihan penggunaan bahasa yang santai tersebut menunjukkan kedekatan dan kehangatannya dengan para tokoh di foto. Unsur persahabatan dan kasih sayang tampak dominan di foto ini. Hal tersebut dengan selaras dengan konsep Pathos yang menyentuh sisi emosional followers. Selain itu dengan menceritakan kedekatan dengan tokoh-tokoh perempuan ternama lainnya, Puti juga ingin menunjukkan bahwa dirinya adalah calon pemimpin yang memiliki kredibilitas tinggi karena tidak sembarang orang bisa mendapat dukungan dari tokoh sekelas Walikota, Menteri dan mantan Presiden. Sehingga pada foto ini gaya retorika Aristoteles yang dominan digunakan adalah Pathos dan Ethos.

\section{Foto 7:}

Menurut foto dan caption ini Puti tampak berpose dengan ayahnya, Guntur Sukarno Putra yang merupakan putra tertua Bung Karno. Putri mengungkapkan dukungan ayah dan ibunya. Namun foto yang dipilih untuk dipajang di IG ini hanya foto yang menyertakan sang ayah dan tidak menyertakan sang ibu. Dengan lugas Puti menyebutkan bahwa kedua orangtuanya merupakan sosok yang sangat mendukung karirnya Sehingga dapat disimpukan bahwa unsur political marketing yang menonjol pada foto ini adalah Figur pendukung. Tidak dapat dipungkiri bahwa nama besar presiden pertama RI merupakan daya tarik tersendiri maka keturunannya seringkali menggunakan nama besar bung Karno untuk meraih simpati masyarakat. Salah satu yang menarik di sini aalah ketika Puti menyebutkan kedua orang tuanya pada caption, namun ia memilih hanya menyertakan sang ayah dalam foto yang ia unggah. Hal tersbeut menimbulkan dugaan bahwa sosok ayah dinilai memiliki daya tarik yang lebih dibanding sang ibu dalam segi menarik perhatian masyarakat.

Jika melihat dari pilihan kata yang digunakan, Puti ingin menunjukkan sifat anak yang menghargai, menghormati dan berbakti pada orang tua. Dengan menjadi sosok anak yang berbakti kepada orangtua, Puti ingin menampilkan pada followersnya bahwa sebagai Cawagub ia memiliki karakter yang terpuji (kredibilitas). Maka unsur retorika Aristoteles yang ia tonjolkan di sini salah satunya adalah Ethos. Selain itu, kata-kata yang menunjukkan rasa terima kasih dan apresiasi kepada kedua orang tua menurut analisa penulis juga bertujuan untuk membangkitkan sisi emosional (kasih sayang) dari followers (Pathos). 


\section{Foto 8:}

Dalam foto yang menuai "love" terbanyak di bulan Mei ini, tampak Puti bersama dengan sosok Megawati Soekarno Putri yang merupakan tante kandungnya sendiri. Caption fot o tersebut berbunyi "Dari beliaulah saya belajar keyakinan, keteguhan hati dan keihklasan dalam pengabdian". Sekali lagi Puti menggunakan unsur figur pendukung (Person) dalam melakukan political marketing di Instagram. Megawati yang pernah menjabat menjadi Presiden RI yang ke-5 merupakan kebanggaan dalam keluarga Soekarno karena hanya ia yang berhasil menduduki kursi nomor 1 di negeri ini menyusul jejak sang ayah. Puti menunjukkan kekagumannya pada sosok Megawati melalui caption tersebut. Ia menegaskan karakter-karakter baik yang ia pelajari dari sosok Megawati dan menitikberatkan pada kata "pengabdian". Puti berusaha meyakinkan followers bahwa keinginannya untuk menduduki kursi no 2 di Jatim semata-mata adalah karena niat untuk mengabdi pada masyarakat. Jadi selain unsur figur pendukung, dalam foto ini ia juga menekankan pada kualitas personal dirinya sendiri sebagai kandidat.

(Figur kandidat/Person). Bahasa tubuh keduanya yang tampak sangat dekat (Megawati mengapit lengan Puti sambil tertawa dan berjalan beriringan) juga menunjukkan kedekatan personal antara sosok tante dan keponakan di luar kedekatan mereka di ranah politik.

Ungkapan kebanggaan sekaligus keteladanan terhadap sosok Megawati yang dituliskan oleh Puti merupakan upaya untuk menunjukkan Puti memiliki niat dan karakter yang baik. Sebagai anggota keluarga yang lebih muda ia memilih untuk meneladani sosok sang tante yang telah lebih dulu berkecimpung di dunia politik dan pemerintahan, Puti juga memuji karakter Megawati yang dinilainya memberi teladan dalam pengabdian kepada bangsa Indonesia. Unsur Ethos dari Retorika Aristoteles tampak dominan pada foto ini. Selain Ethos, unsur Pathos juga sarat terlihat dalam foto ini, terlihat dari pilihan kata yang digunakan Puti untuk mendeskripsikan karakter Megawati yang ia teladani. Ada unsur kasih sayang, kekaguman yang ingin dibangkitkan melalui perkataan yang ia tulis di sini.

\section{Foto 9 :}


Di foto ini Puti tampak berpose dengan perwakilan dari partai pendukungnya. Caption yang tertulis di sana mewakili paham yang menjadi ideologi masing-masing partai pendukung Puti. Mulai dari religius (PKS), nasionalis (Gerindra), Sukarnois (PDIP), dan Nadhliyis (PKB). Melalui caption foto tersebut Puti ingin menunjukkan kekuatan-kekuatan yang mendukungnya dan Gus Ipul untuk maju menjadi pemimpin Jatim. Ia menonjolkan unsur keberagaman figur pendukungnya. Jadi dapat disimpulkan bahwa pada foto yang menuai "love" terbanyak kedua ini, Puti menggunakan figur pendukung (Person) sebagai alat political marketing-nya. Untuk membuktikan keberagaman partai, pada foto ini Puti mengenakan kerudung berwarna hijau yang menjadi lambang partai asal Gus Ipul yaitu PKB (padahal biasanya hampir di setiap foto dalam akun Instagramnya Puti mengenakan kerudung hitam atau merah yang menjadi warna lambang PDIP).

Dari gaya retorika yang Puti sampaikan di foto ini, Puti menunjukkan bahwa ia memiliki kredibilitas yang tinggi berupa niat baik dan karakter terpuji (Ethos) karena mendapat dukungan dari partai yang begitu beragam. Melalui figur-figur pendukungnya Puti ingin meyakinkan masyarakat bahwa jika ia terpilih menjadi Wagub Jatim, maka masyarakat tidak perlu khawatir karena ia mendapatkan dukungan dari banyak pihak yang kompeten dan berpengaruh. Gaya dan ekspresi objek pada foto yang tampak santai, ceria dan berdiri saling berdekatan ingin memberikan kesan bersahabat dan ramah bagi para followers yang melihat foto tersebut. Upaya untuk menyentuh sisi emosional tersebut masuk ke dalam kategori Pathos dalam Retorika Aristoteles.

\section{Foto 10:}

Merupakan foto terakhir yang diunggah di hari pencoblosan Pilkada pada 27 Juni yang lalu. Puti berpose bersama Walikota Surabaya Tri Risma Harini. Caption pada foto tersebut mengajak warga Jatim untuk ikut serta memberikan suaranya. Caption yang Puti gunakan di sini tampak biasa, hanya berupa ajakan bagi warga untuk menggunakan hak pilihnya. Ia berfoto bersama orang nomor 1 di Surabaya untuk sekali lagi menunjukkan bahwa ia mendapat dukungan dari Ibu Walikota. Puti sendiri tidak melakukan pemilihan di Jawa Timr karena alamat berdasarkan KTP-nya masih bertempat di Jawa Barat. Figur pendukung (Person) merupakan unsur political marketing yang paling terlihat digunakan pada foto ini. 
Kemudian dilihat dari perkataan yang ia sampaikan di caption, Puti tampak menggunakan unsur logos dari retorika Aristoteles. "Ayo, gunakan hak pilihmu hari ini. Jangan lupa, ya.(emotion icon senyum) Berikan yang terbaik untuk Jawa Timur.” Puti mengajak agar warga menggunakan hak pilih mereka agar dapat memberi hasil yang terbaik untuk Jawa Timur. “Terbaik” pada konteks ini tidak merujuk pada Gus Ipul dan dirinya. Puti tampak ingin menyampaikan pesan yang bernuansa netral, namun jika dilihat dari foto, Bu Risma dan kedua laki-laki yang ada di dalam frame tampak mengacungkan kedua jari kanannya melambangkan angka 2 yang merupakan nomor urut Gus Ipul dan Puti. Sehingga pilihan “terbaik" yang dimaksud dalam foto dan caption tersebut secara tersirat merujuk pada pasangan nomor urut 2.

Berdasarkan uraian di atas terlihat bahwa dari segi political marketing isi akun Instagram Puti banyak didominasi oleh foto-foto yang menonjolkan unsur figur kandidat dan pendukung serta partai. Puti memang memposting foto yang "menjual" rencana program-program dan kebijakannya namun proporsinya tidak seberapa dan tidak pula menuai tanda "love" dari para followersnya. Melihat pola demikian maka dapat dikatakan fokus political marketing Puti masih berkisar pada pencitraan dirinya sebagai kandidat Cawagub Jatim. Puti yang belum begitu terkenal membutuhkan bantuan untuk menggapai popularitasnya melalui dukugan tokoh-tokoh ternama yang berada di sekitarnya. Namun dengan demikian potensi diri Puti yang sesungguhnya menajdi tidak terlalu terlihat. Apabila melihat hasil quick count Pilkada 2018 , pasangan Khafifah dan Emil Dardak mengungguli pasangan Gus Ipul dan Puti strategi yang dilakukan Puti tampak belum cukup untuk mengambil hati warga Jatim.

Sedangkan jika menganalisa dari sisi Retorika Aristoteles, unsur Ethos dan Pathos adalah yang paling dominan digunakan oleh Puti. Keduanya mendukung unsur figur kandidat, pendukung dan partai yang menjadi topik utama dalam political marketing Puti Soekarno. Unsur Logos juga digunakan oleh Puti namun hanya sedikit di antara postingan foto yang mendapatkan "love" terbanyak. Ethos yang berarti menunjukkan niat dan karakter baik amat sering ditonjolkan oleh Puti. Unsur Pathos yang berusaha menggugah sisi emosional juga kental terasa Namun postingan Puti tampaknya kurang banyak yang menonjolkan sisi Logos. Padahal dengan menggunakan argumen yang masuk akal, Puti dapat mendekatkan diri kepada khalayak dan meraih simpati dengan meyakinkan mereka dari sisi intelektual.

\section{KESIMPULAN}


Dari berbagai penjabaran yang telah penulis lakukan, bisa ditarik kesimpulan bahwa Foto 6 dari Instagram @ puti_soekarno adalah foto dengan jumlah likes terbanyak dari 9 Foto lainnya. Foto tersebut mendapat jumah "love" paling banyak, yaitu 11, 879. Foto tersebut bercerita tentang Puti yang sedang berada di dalam mobil bersama tiga orang tokoh politik dan pemerintahan, yaitu Tri Rismaharini Walikota Surabaya, Susi Pujiastuti Menteri Kelautan dan Perikanan serta Megawati Soekarno Putri ketua umum PDIP. Kedekatan ini juga diisyaratkan sebagai bentuk dukungan tokoh-tokoh tersbeut terhadap Puti. Foto tersebut, jika menganalisa dari sisi Retorika Aristoteles, unsur yang digunakan adalah Ethos dan Pathos. Keduanya mendukung unsur figur kandidat, pendukung dan partai yang menjadi topik utama dalam political marketing Puti Soekarno. Jika menganalisa dari segi Political Marketing, Figur Pendukung, Figur Kandidat dan Partai sangat lekat dalam Foto tersebut.

\section{DAFTAR PUSTAKA}

A.Griffin, Emory. 2003. A First Look at Communication Theory. Fifth Edition. Boston: McGraw-Hill

Barthes. Roland. 1964. Element of Semiology. Paris: Jonathan Cape

Chandler. Daniel. 2007. Semiotics : The Basic. New York: Routledge. Buku Elektronik.

D. Iryani. Ana. 2013. Naskah Publikasi Personal Branding Jokowi dalam Media (Analisis Isi Kuantitatif Personal Branding Jokowi dalam Harian Solopos Periode Terbit Maret - Juli 2012). Universitas Muhammadiyah Surakarta

Firmanzah. 2008. Marketing Politik. Jakarta: Yayasan Pustaka Obor Indonesia

Nimno. Dan. 2000. Komunikasi Politik, Komunikator, Pesan dan Media. (Cetakan Kesepuluh). Bandung: Remaja Rosda Karya

Soetomo. 2013. Jurnal Personal Branding dalam Peningkatan Elektabilitas (Studi Kekuatan Foto Ganjar Pranowo Pada Pemilihan Gubernur Jawa Tengah 2013) 